\title{
Attenuation of gastrointestinal tract propulsion in rats by zinc acetate: Investigation into serotonergic and dopaminergic mechanisms
}

\author{
Rufus Ojo Akomolafe ${ }^{1,}$, , Olusoji Adeola Adalumo ${ }^{1}$, Kayode Dominion Samuel Bamitale ${ }^{2}$ \\ ${ }^{1}$ Department of Physiological Sciences/Faculty of Basic Medical Sciences, Obafemi Awolowo University, Ile-Ife, Osun-State Nigeria \\ ${ }^{2}$ Department of Medical Pharmacology and Therapeutics/Faculty of Basic Medical Sciences, Obafemi Awolowo University, Ile-Ife, \\ Osun-State Nigeria
}

Email address:

rufakom@yahoo.co.uk (R. O. Akomolafe), infosoj@gmail.com (O. A. Adalumo),drkdsbam@yahoo.com (K. D. S. Bamitale)

To cite this article:

Rufus Ojo Akomolafe, Olusoji Adeola Adalumo, Kayode Dominion Samuel Bamitale. Attenuation of Gastrointestinal Tract Propulsion in Rats by Zinc Acetate: Investigation into Serotonergic and Dopaminergic Mechanisms. American Journal of Life Sciences.

Vol. 2, No. 6, 2014, pp. 406-412. doi: 10.11648/j.ajls.20140206.22

\begin{abstract}
This study evaluated the influence of orally administered zinc acetate on gastrointestinal tract propulsion of rats. It also evaluated the effects of the salt on faecal output and gastrointestinal transit time in the rats. The effects of zinc acetate on feeding as well as water intake were determined. The dose of zinc acetate which produced the maximal effect was used to investigate the receptors involved in the alteration of gastrointestinal motility by the salts. All the three doses of zinc acetate ( 50 $\mathrm{mg} / \mathrm{kg}, 80 \mathrm{mg} / \mathrm{kg}$ and $110 \mathrm{mg} / \mathrm{kg}$ ) produced a significant reduction in the number of total faecal pellets produced in eight hours of study $(2.67 \pm 0.67,10.75 \pm 0.60,5 \pm 0.52)$ respectively when compared with the control group $(15.67 \pm 0.52)$. Also, the three doses of zinc acetate produced a dose-dependent significant reduction in the faecal mass $(1.23 \pm 0.08 \mathrm{~g}, 0.96 \pm 0.07 \mathrm{~g}, 0.59 \pm 0.07 \mathrm{~g})$ respectively when compared with control group $(3.39 \pm 0.25 \mathrm{~g})$. The total transit time in rats treated with $50 \mathrm{mg} / \mathrm{kg}$ of zinc acetate (746.2 \pm 5.95 minutes) increased significantly compared to the control group (251.2 \pm 5.48 minutes). The three doses of zinc acetate produced a dose-dependent reduction $(\mathrm{p}<0.05)$ in food intake $(9.67 \pm 0.61,9.17 \pm 0.62$ and $5.00 \pm 0.39)$ respectively compared to the control group $(18.33 \pm 0.67)$. Pre-treatment with metoclopramide $\left(5 \mathrm{HT}_{3} \& \mathrm{D}_{2}\right.$ blocker/5HT $\mathrm{H}_{4}$ serotonergic agonist) significantly increased faecal pellet output in zinc acetate treated rats $(4.80 \pm 0.20)$ when compared with rats treated with zinc acetate alone $(2.67 \pm 0.67)$. The study concluded that zinc acetate reduced gastrointestinal tract propulsion in rats evidenced as increased intestinal transit time of rats and reduced faecal pellet output via stimulation of $5 \mathrm{HT}_{3}$ and $5 \mathrm{HT}_{4}$ serotonergic and dopaminergic receptors.
\end{abstract}

Keywords: Zinc Acetate, Gastrointestinal Propulsion, Serotonergic Receptors and Transit Time

\section{Introduction}

Gastrointestinal (GI) motor activity involves a complex group of functions that are essential for life (Huizinga and Lammers, 2009). Disorders of GI transit and/or contractility are common (Rao et al., 2011). Gastric emptying is also complex and consisting of interconnected parts reflecting a variety of functions which include accommodation and coordinated relationship between the proximal/distal stomach and antropyloroduodenal contractility (Szarka and Camilleri, 2009). Appetite is the natural craving for food which is evidenced as hunger, resulting in increased food consumption. Satiety or satiation have opposite effect to elicit a sense of satisfaction on feeding. These are important physiologic phenomena which help to ensure adequate food intake for the maintenance of the body metabolic needs. Brain centres are known to regulate feeding and satiety through neuropeptides responsible for energy homeostasis amongst other regulating and modulating pathways. Zinc acetate is reputed for its potency in the treatment of diarrhea. However, the receptors involved in its ameliorative effects on gastrointestinal dysfunctions need more studies. The effect of zinc acetate on food consumption and water intake is also yet to be investigated, hence this study. 


\section{Materials and Methods}

\subsection{Experimental Animals}

Twenty-four male adult Wistar rats weighing 120 - $180 \mathrm{~g}$ were obtained from the Animal House of Benue State University, Makurdi and kept in plastic rat cages for two weeks to acclimatize in the Animal Holding, Department of Anatomy and Cell Biology, where they were given access to feed (Caps Feed, Osogbo) and water ad-libitum. The rats were randomly divided into four groups consisting six rats each. Group 1 was given distilled water and served as the Control, Group 2, 3 and 4 received 50, 80 and $110 \mathrm{mg} / \mathrm{kg} /$ day oral administration of zinc acetate respectively (Medici et al., 2005).

\subsection{Test on 5-HT ${ }_{3,4}$ and Dopamine Receptors}

Metoclopramide hydrochloride injection B.P $10 \mathrm{mg}$ contained in $2 \mathrm{ml}$ ampoule was used. It was manufactured by: Anhui ChengShi Manufacture Medicine Co., Ltd. Hebei New industrial park, Bengbu, Anhui. China. For: Embassy Pharmaceutical and Chemicals Limited, Lagos Nigeria. Item No.: E.M-231715, Mfg.Lic No.:20100206, Batch No.:121108, Manufacturing. Date: 11/2012, Expiry Date: 11/2015, NAFDAC Reg. No.:A4-0034. This was administered intramuscularly at $5 \mathrm{mg} / \mathrm{kg}$ for 15 minutes before administration of the zinc salt. Faecal pellets were counted at two-hour intervals for eight hours following zinc salt administrations. The weight of the air-dried pellets were determined after 24-hours.

\subsection{Food and Water Intake}

Food consumption was determined by measuring the differences in pre and post observation weight of the food pellets. Water intake was determined by subtracting the volume of water left after observation from the volume before observation started.

\subsection{Statistical Analysis}

Statistical analyses were carried out using Graphpad Prism 5.0 version software. Data are presented as mean \pm SEM. Analysis of Variance (ANOVA) was performed followed by Newman Keuls' post-hoc test. A value of $p<0.05$ was considered statistically significant.

\section{Results}

\subsection{Effect of Zinc Acetate on Food Intake}

Fig. 1 shows pre-treatment with zinc acetate $(50 \mathrm{mg} / \mathrm{kg}, 80$ $\mathrm{mg} / \mathrm{kg}$ and $110 \mathrm{mg} / \mathrm{kg}$ ) produced a dose-dependent reduction in food intake $(9.67 \pm 0.61,9.17 \pm 0.62$ and5.00 \pm 0.39$)$ respectively when compared to the control group (18.33 \pm 0.67) $(\mathrm{p}<0.05)$ with the $110 \mathrm{mg} / \mathrm{kg}$ dose producing the highest inhibition $(5.00 \pm 0.39)$.

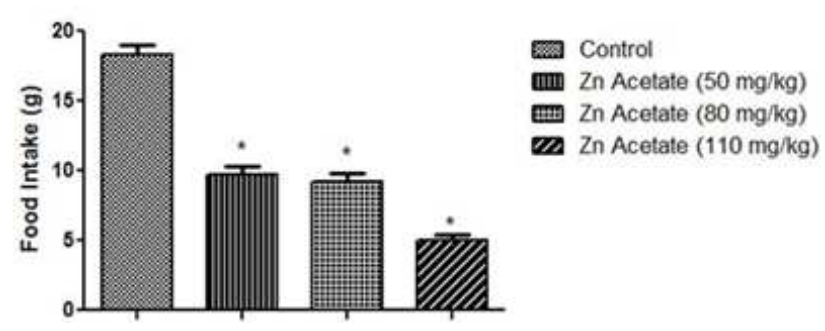

Fig 1. Zinc Acetate on Feeding Pattern

\subsection{Effect of Zinc Acetate on Water Intake}

Pre-treatment with zinc acetate $(50 \mathrm{mg} / \mathrm{kg}, 80 \mathrm{mg} / \mathrm{kg}$ and $110 \mathrm{mg} / \mathrm{kg})$ significantly reduced $(\mathrm{p}<0.05)$ water intake $(13.45 \pm 0.76,17.17 \pm 0.60$ and $8.71 \pm 0.73)$ respectively when compared to the control group $(21.42 \pm 0.93)$ and the $110 \mathrm{mg} / \mathrm{kg}$ dose producing the highest inhibition $(8.71 \pm 0.73)$ (Fig 2).

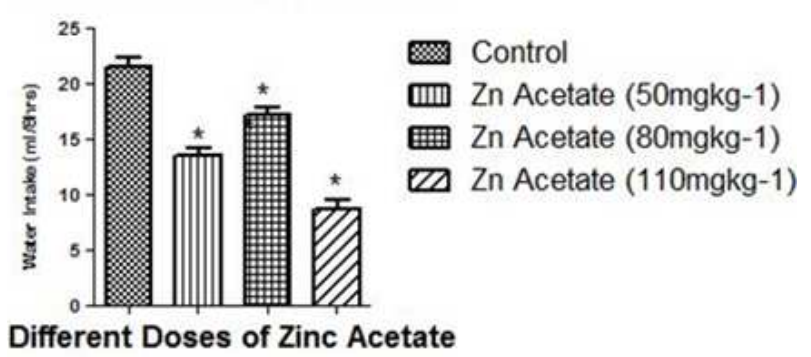

Fig. 2. Zinc Acetate on Water Intake

\subsection{Effect of Zinc Acetate on Faecal Output}

All the three doses of zinc acetate $(50 \mathrm{mg} / \mathrm{kg}, 80 \mathrm{mg} / \mathrm{kg}$ and $110 \mathrm{mg} / \mathrm{kg})$ produced a significant reduction $(\mathrm{p}<0.05)$ in the number of total faecal pellets $(2.67 \pm 0.67,10.75 \pm 0.60$, $5 \pm 0.52)$ respectively when compared to the control group $(15.67 \pm 0.52)$. Of the three doses of zinc acetate, $50 \mathrm{mg} / \mathrm{kg}$ produced the highest reduction in number of total faecal pellet in 8 hours $(2.67 \pm 0.67)$ while $80 \mathrm{mg} / \mathrm{kg}$ produced the least reduction in 8 hours $(10.75 \pm 0.60)$. In the first time interval $\left(2^{\text {nd }}\right.$ hour $)$ only $50 \mathrm{mg} / \mathrm{kg}$ produced significant reduction $(\mathrm{p}<0.05)(0.33 \pm 0.21)$ in faecal number when compared to the control group $(1.67 \pm 0.33)$ (Fig 3$)$.

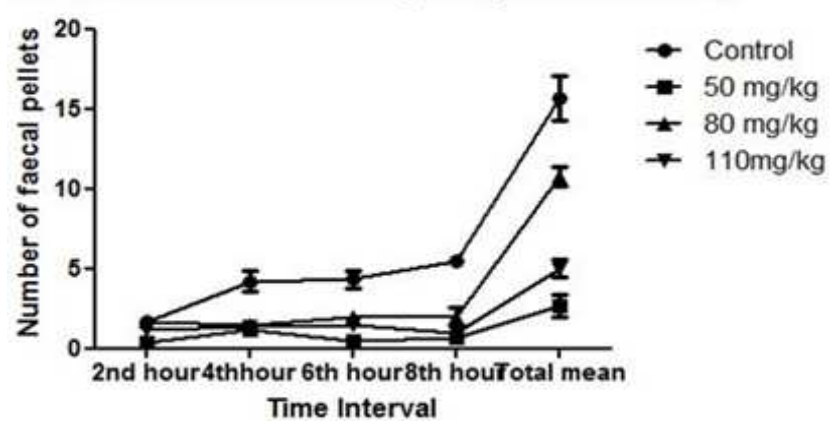

Fig 3. Effect of Zinc Acetate on Frequency of Defecation

At the second time interval (4th hour) $50 \mathrm{mg} / \mathrm{kg}, 80 \mathrm{mg} / \mathrm{kg}$ and $110 \mathrm{mg} / \mathrm{kg}$ significantly reduced $(\mathrm{p}<0.05)$ the number of 
faecal pellets $(1.17 \pm 0.17,1.5 \pm 0.22,1.33 \pm 0.33)$ respectively when compared to the control group (4.17 \pm 0.65 ). At the third time interval (6th hour) all the three doses also significantly reduced $(\mathrm{p}<0.05)$ the number of faecal pellets $(0.50 \pm 0.22,2.0 \pm 0.00,1.50 \pm 0.22)$ respectively compared to control group $(4.33 \pm 0.56)$. Lastly, at the fourth time interval (8th hour) all the three doses significantly reduced $(\mathrm{p}<0.05)$ the number of faecal pellets $(0.67 \pm 0.21$, $2.0 \pm 0.52,1.00 \pm 0.37)$ respectively compared to control group $(5.5 \pm 0.22)$.

\subsection{Effect of Zinc Acetate on Faecal Weight}

All the three doses of zinc acetate $(50 \mathrm{mg} / \mathrm{kg}, 80 \mathrm{mg} / \mathrm{kg}$ and $110 \mathrm{mg} / \mathrm{kg}$ ) produced a dose-dependent significant reduction $(\mathrm{p}<0.05)$ in the faecal weight $(1.23 \pm 0.08,0.96 \pm$ $0.07,0.59 \pm 0.07)$ respectively when compared to control group $(3.39 \pm 0.25)$. Of the three doses of zinc acetate, 110 $\mathrm{mg} / \mathrm{kg}$ produced the highest reduction in faecal weight in 8 hours $(0.59 \pm 0.07)$ while $50 \mathrm{mg} / \mathrm{kg}$ produced the least in 8 hours $(1.23 \pm 0.08)$. In the first time interval $\left(2^{\text {nd }}\right.$ hour $)$ all the three doses produced significant reduction $(\mathrm{p}<0.05)(0.15 \pm$ $0.03,0.22 \pm 0.01,0.14 \pm 0.01)$ in faecal weight when compared with control group $(0.55 \pm 0.05)$ (Fig 4$)$.

At the second time interval ( $4^{\text {th }}$ hour) $50 \mathrm{mg} / \mathrm{kg}, 80 \mathrm{mg} / \mathrm{kg}$ and $110 \mathrm{mg} / \mathrm{kg}$ significantly reduced $(\mathrm{p}<0.05)$ the faecal weight $(0.54 \pm 0.03,0.2 \pm 0.01,0.16 \pm 0.02)$ respectively compared to control group $(0.76 \pm 0.07)$. At the third time interval $\left(6^{\text {th }}\right.$ hour $)$ all the three doses also significantly reduced $(\mathrm{p}<0.05)$ the faecal mass $(0.23 \pm 0.01,0.27 \pm 0.02$, $0.18 \pm 0.02)$ respectively compared to control group $(0.73 \pm$ $0.03)$. Lastly, at the fourth time interval ( $8^{\text {th }}$ hour) all the three doses significantly reduced $(\mathrm{p}<0.05)$ the faecal mass $(0.31 \pm$ $0.01,0.27 \pm 0.01,0.12 \pm 0.11)$ respectively compared to control group (1.36 \pm 0.12$)$ (Fig 4).

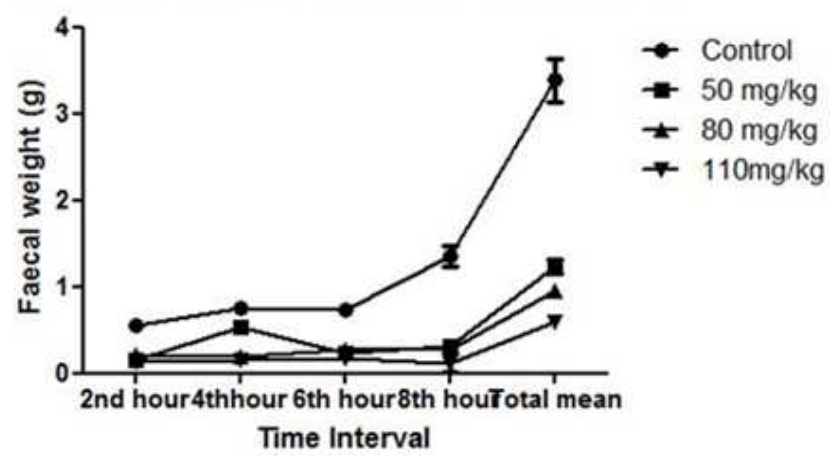

Fig 4. Effect of Zinc Acetate on Weight of Faecal Pellets

\subsection{Effect of Zinc Acetate on Gastrointestinal Transit Time Using Charcoal Meal}

Fig 5 shows the total transit time of zinc acetate $(50 \mathrm{mg} / \mathrm{kg})$ treated group $(746.2 \pm 5.95 \mathrm{~min})$ increased significantly $(\mathrm{p}<$ $0.05)$ compared to the control group $(251.2 \pm 5.48 \mathrm{~min})(\mathrm{p}<$ $0.05)$.

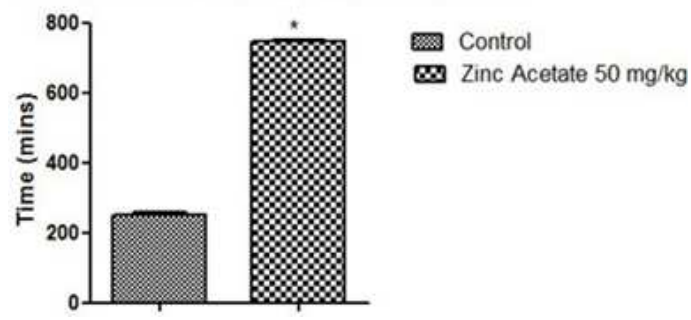

Fig 5. Gastrointestinal Transit Time in Rats

\section{Discussions}

Pre-treatment with zinc acetate produced a dose-dependent reduction in food intake when compared to the Control group that received only distilled water. The highest dose of zinc acetate $(110 \mathrm{mg} / \mathrm{kg})$ produced the highest inhibition of appetite in the experimental animals.

Appetite is the natural craving for food which is evidenced as hunger, resulting in increased food consumption. It is an important physiologic phenomenon which helps to ensure adequate food intake for the maintenance of the body metabolic needs. Brain centres are known to regulate feeding and satiety through neuropeptides responsible for energy homeostasis. These centres include the hypothalamus, brainstem and reward centres. Circulating gut hormones modulate these pathways acutely resulting in the stimulation of appetite or satiety behaviours. The observed effect of the tested doses of zinc acetate on food intake was mediated through one or combination of several of the mechanisms explained below.

The first is the role of $\mathrm{G}$ protein-coupled receptors (GPR39) in appetite regulation. In the brain, high levels of this molecule are detected across the septum and in distinct cells of amygdala and hippocampus in human and rodents [6-8]. Contrary to the study of Zhang et al., 2005 [9], some investigators did not find GPR39-1a expression in the hypothalamus [7-8, 10-11]. Therefore a possible role of GPR39 in the regulation of food intake may depend on non-hypothalamic pathways, such as the septum which is involved in the rewarding aspects of feeding and hyperphagia [12].

Studies have pointed to a relationship between plasma levels of zinc and leptin system in humans and rodents [13-14] These studies established a positive correlation between both zinc and leptin levels, possibly by increasing the production of cytokines (IL-2 and TNF-a) which in turn increases circulating leptin concentration in rodents leading ultimately to reduction in appetite [15]. This is one of the clear signaling pathway in accord with the anorexigenic effect of zinc acetate at high doses observed in this experiment.

Chen et al., [16-17] observed increased leptin at low zinc levels and further zinc supplementation to the experimental animals in the same study stimulated further increase in leptin levels. This implies that zinc may either directly affect leptin gene expression or indirectly cause leptin production. It was reported that zinc deficiency inhibited leptin secretion from the fatty tissue, whereas supplementation of a physiological 
dose of zinc increased both leptin levels and glucose intake in mice.

Again the anorectic effect of zinc salts at high doses may be explained by the mechanism of peripheral signals from adipose tissue. Leptin is secreted from adipose tissue to regulate energy homeostasis [18]. Zinc acetate at high doses probably caused the release of leptin from the adipose tissues leading to increased circulating levels of leptin which then results in reduced food intake. Other investigators showed that the nuclei of tractus solitarius (NTS) like the arcuate nucleus (ARC), contains leptin receptors and leptin administration to the fourth ventricle resulted in a reduction in food intake. [19]. Peripheral administration of leptin also resulted in neuronal activation within the NTS [20-21]. Thus zinc acetate evidently exert its effect indirectly on appetite via leptin's action on both the hypothalamus and brainstem.

Another probable mechanism of action of the zinc acetate is by increasing or decreasing circulating levels of insulin. Insulin is synthesized by the pancreas and released to exert its metabolic functions on the body cells. Zinc is found in $\alpha$ and $\beta$ cells of pancreas and was shown to be actually necessary in $\beta$ cells for the synthesis, storage and release of insulin [22]. Zinc was found to potentiate the activity of insulin signaling pathway [22] and In vivo zinc depletion led to decreased insulin secretion and diminished cellular sensitivity to insulin [23].

\subsection{Reduction of Water Intake by Zinc Acetate}

All the three doses of zinc caused a reduction in water intake. Thirst is the sensation that brings the impulse to drink fluids especially water. It is one of the regulatory mechanisms that maintain body fluid homeostasis and ultimately is essential for survival. The idea of a thirst "center" per se is being substituted with the new concept of a complex neural circuitry regulating fluid intake [24].

The result of this study is in line with earlier studies where zinc salts elicited significant antidipsogenic effects at all those levels. Fregoneze and other investigators had demonstrated that central administration of zinc in minute amounts induced a significant antidipsogenic action in dehydrated rats. They also showed that dehydrated rats under central cholinergic and angiotensinergic stimulation experienced antidipsogenic response to zinc treatment [25]. Further studies by this group demonstrated that zinc induced blockade of water intake in dehydrated rats may be, at least in part, due to stimulation of central opioid peptides [26].

The inhibitory effect of zinc acetate on water intake largely relates with the anorexigenic effect of the salts in rats, suggesting some common signaling pathways or mechanisms. Atrial Natriuretic Peptide (ANP) and Glucagon-like Peptide1 (GLP 1) have been shown to inhibit water intake [27-29]; secondary to inhibition of feeding since GLP 1 have been previously linked with inhibition of feeding in rodents [30].

Zinc acetate inhibit water drinking indirectly through these two peptides, although other possible mechanisms may be involved. Osmoreceptors are specialised neurons situated on the walls surrounding the $3 \mathrm{rd}$ ventricle which are not covered by the blood-brain-barrier (BBB), and are hence exposed to salts circulating in the bloodstream. These receptors are mostly found within the hypothalamus, and may also be found in the gut. The osmoreceptors send neural signals to supraoptic and paraventricular nuclei of the hypothalamus which in turn send separate signals to [1] posterior pituitary to secrete increased amounts of $\mathrm{ADH}$, which causes decreased amounts of urine formed [2] lateral preoptic area of the hypothalamus which increased drinking. Zinc acetate is thought to indirectly inhibit these pathways through GLP 1 and ANP.

Calcium channel blockers were found to inhibit the antidipsogenic effect of central injections of zinc in rats [31]. SDZ 216-525, a selective 5-HT ${ }_{1 \mathrm{~A}}$ receptor antagonist, reverted zinc-induced inhibition of water intake in dehydrated rats. Other studies also demonstrated the inhibition of enkephalin binding to opiate receptors by zinc ions [32].

Brain angiotensinergic and cholinergic components stimulate water intake, whereas opioids and serotonin have the opposite effect [33]. It has been established that water intake stimulated by central $\beta$-adrenergic stimulation is blocked by zinc. It was also shown that the inhibitory effect of zinc on water intake might be opioid-dependent. [26].

\subsection{The Effect of Graded Doses of Zinc Acetate on Faecal Pellet Output of Rats}

Gastric emptying, gut transit and faecal output are direct products of gut motility/contractility and or peristalsis. Gut motility itself is regulated by many concerted signaling pathways and mechanisms. "A crucial advantage of multiple control systems is that gut motility control can withstand injury to one or more of its components" [1]. Therefore the inhibitory effect of the zinc acetate cannot be attributed to just one of these mechanisms.

The reduction in faecal pellet output induced by graded doses of zinc acetate $(50 \mathrm{mg} / \mathrm{kg}, 80 \mathrm{mg} / \mathrm{kg}$ and $110 \mathrm{mg} / \mathrm{kg}$ ) was not dose-dependent. However, the reduction induced by zinc acetate was dose dependent. All the doses of zinc acetate used in this study induced significant reductions in both the mass and number of faecal pellets of the experimental rats compared to the control.

These results showed that zinc acetate reduced gut motility ultimately resulting in fewer faecal pellets within the period of evaluation. The contrasting result in the number of faecal pellet and the faecal mass produced suggests that, while the least dose of zinc acetate $(50 \mathrm{mg} / \mathrm{kg})$ produced the least number of pellets, the pellets produced had more fluid content while the highest dose tested $(110 \mathrm{mg} / \mathrm{kg})$ produced drier faeces. Evidently, zinc acetate had proven to be potent at reducing the frequency of defecation while also promoting the absorption of water and electrolytes from the small intestine and the colon.

The physiologic mechanism by which water is absorbed from the lumen of the small intestine and the colon is by the coupled activity of the sodium/hydrogen exchanger and chloride bicarbonate exchanger in the apical membrane (electroneutral mechanism). Water follows this movement to 
sustain osmotic balance immediately. Additionally, there is electrogenic absorption of sodium from the distal colon where sodium enters the epithelial cells via epithelial sodium channels $(\mathrm{ENaC})$. This $\mathrm{ENaC}$ is identical to the type found in the kidneys which is the reason why it is possible for the distal colon to achieve a remarkable desiccation of faeces.

The production of drier faeces as evidenced by reduction in faecal mass is supported by the action of zinc to suppress drinking by the rats in this experiment. A reduction in water intake expectedly increases absorption of water from the intestine. Another mechanism by which more water can be absorbed from the lumen of the small intestine is by increasing the surface area for reabsorption. Zinc has been shown to increase the absorption surface of the small intestine. This is because of its importance in DNA synthesis and increase mRNA in cells leading to enhancement of cell division and rapid growth of cells of the epithelium which also is one of the most rapidly dividing cells or tissues in the body. The reduction in faecal output can also be attributed to the anorexigenic effect of the salts on the rats during the experiments.

Food intake induces propagating, propulsive contractile activity, either by chemical or mechanical properties of the food, through autonomic reflexes or hormonal actions [34-36]. It is obvious from this study that a positive correlation exists between faecal output and food intake, a pointer to the fact that reduced feeding actually caused slight reduction in motility as previously described [34-36].

\subsection{Zinc Acetate on Gastrointestinal Transit Time}

The result of this study established the effect of slow transit constipation in the experimental rats treated with zinc acetate. Furthermore, the salt reduced the frequency of defecation by the rats and also altered the consistency or form of the pellets; making the faecal pellets harder. The entire transit time of the GIT is the time interval between charcoal meal ingestion and its exit from the body $[5,37]$.

The time taken (in minutes) for charcoal to travel the total length of the gastrointestinal tract was determined after pre-treatment with the most effective dose of zinc acetate compared to the control group pre-treated with distilled water. The most effective dose of zinc acetate delayed the transit time in the rats. Zinc acetate $(50 \mathrm{mg} / \mathrm{kg})$ produced the highest transit time (746.2 \pm 5.95 minutes $)$.

Zinc has the ability to bind to many cell-surface proteins.
These include ion channels, neurotransmitter transporters and seven transmembrane domain (7TM), G protein-coupled receptors one of which is GPR39. $(38,39)$. GPR39, one of the trans-membrane receptor of ghrelin receptor family is ubiquitous in many tissues such as; endocrine, gut, liver, adipose tissue and the endocrine pancreas [40]. Substantial facts point to zinc as the agonist for GPR39 and various studies had established $\mathrm{Zn}^{2+}$ as a GPR39- activating factor [41, 10 and 42]. The unique binding of $\mathrm{Zn}^{2+}$ to GPR39 indicates that $\mathrm{Zn}^{2+}$ is a real ligand rather than an allosteric regulator [43].

Expectedly, gastric emptying was increased in GPR39 knockout mice. Also, transit and expulsion of faeces was more effective from the colon of GPR39 knockout mice [7]. These findings proposes that GPR39 agonists may inhibit gastric and colonic motility. This agrees with the impact of the zinc salt tested on faecal pellet output and gut transit in this study.

There is a strong evidence in favour of opiatergic signaling as one of the many pathway through which the zinc salts alter GIT transit and faecal output in this study although this require further studies for confirmation. Opioid receptors has been reported to be widely distributed in the gastrointestinal tract (GIT) [44]. This is supported by the fact that opioids can alter the physiological function of almost all the part of the GIT [45, 46] especially motility and secretion. This accounts for the observed constipating side effect of many opioid analgesics and the commonly prescribed opioid analgesic agents are most selective towards the $\mu$-receptor with essentially negligible effect on $\delta$-receptors [44]. Some of the effects include; delayed gastric emptying, increased overall transit time of food and decreased secretion in the small intestine, decreased frequency of contraction and secretion in the colon leading to constipation, harder and drier stools.

\subsection{The Effect of Metoclopramide on Zinc Acetate-Induced Reduction in Faecal Output of Rats}

Pretreatment with metoclopramide resulted in increased faecal output across the different groups of zinc salt treatment. Metoclopramide blocks dopamine and $5 \mathrm{HT}_{3}$ receptors while activating $5 \mathrm{HT}_{4}$ receptors. This will normally result in increased gastrokinetic activity in the gut. It stimulates motility of the upper gastrointestinal tract without stimulating gastric, biliary or pancreatic secretions. The rate of gastric emptying is increased due to increased peristalsis of the jejunum and duodenum.

Table 1. Effect of Metoclopramide on Zinc Induced Alteration of Faecal Pellet Output.

\begin{tabular}{|c|c|c|c|c|c|}
\hline Column1 & $90^{\text {th }}$ Minute & $180^{\text {th }}$ Minute & $270^{\text {th }}$ Minute & $360^{\text {th }}$ Minute & Total Mean \\
\hline Control & $1.67 \pm 0.33$ & $4.17 \pm 0.65$ & $4.33 \pm 0.56$ & $5.50 \pm 0.22$ & $15.67 \pm 1.38$ \\
\hline Metoclopramide Control & $2.60 \pm 0.24^{\alpha}$ & $1.60 \pm 0.24^{\alpha}$ & $4.40 \pm 0.24$ & $6.00 \pm 0.55$ & $14.60 \pm 0.24$ \\
\hline Zinc Acetate $(50 \mathrm{mg} / \mathrm{kg})$ & $0.33 \pm 0.21^{\alpha}$ & $1.17 \pm 0.17^{\alpha}$ & $0.50 \pm 0.22^{\alpha}$ & $0.67 \pm 0.21^{\alpha}$ & $2.67 \pm 0.67^{*}$ \\
\hline Metoclopramide + Zinc & $0.00 \pm 0.00^{\alpha}$ & $0.40 \pm 0.24^{\alpha \beta}$ & $1.40 \pm 0.24^{\alpha \beta}$ & $3.00 \pm 0.00^{\alpha \beta}$ & $4.80 \pm 0.20^{* \beta}$ \\
\hline
\end{tabular}

*-significantly different from control, $\alpha$-significantly different from control at a given time interval, $\beta$-Significantly different from zinc acetate $(50$ mg/kg) $(\mathrm{P}<0.05)$.

Metoclopramide potently inhibited the effect of zinc salts on faecal output. G.I transit, motility and contractility was significantly increased compared to the group that received

zinc salts alone. This suggest a role for 5HT and dopamine receptors in zinc alteration of gut motility function. $\mathrm{Zn}^{2+}$ was demonstrated to inhibit binding and/or activation of the $\mathrm{D}_{4}$ 
dopamine receptor and the $\mathrm{D}_{2}$ dopamine receptor [47-49].

\section{Conclusion}

Zinc Acetate slowed down gut motility as revealed by increased transit time and decreased faecal output in Wistar rats. It suppresses food intake at doses tested. Further, it also reduced water intake in the experimental animals. This effects of zinc salts are achieved through many concerted signaling pathways and mechanisms where zinc acts as allosteric modulator on the receptors implicated, such as $\mathrm{D}_{2}, 5 \mathrm{HT}_{3}$ and $5 \mathrm{HT}_{4}$.

\section{References}

[1] Huizinga J.D and Lammers W.J (2009). Gut peristalsis is governed by a multitude of cooperating mechanisms. American Journal of Physiology 296:G1-G8

[2] Rao S.S, Camilleri M and Hasler W.L (2011). Evaluation of gastrointestinal transit in clinical practice: position paper of the American and European Neurogastroenterology and Motility Societies. Journal of Neurogastroenterology and Motility 23: $8-23$.

[3] Szarka L.A and Camilleri M (2009). Methods for measurement of gastric motility. American Journal of Physiology, 296:G461-G475.

[4] Medici V, Sturniolo G.C, Santon A, D'Incà R, Bortolami M, Cardin R, Basso D, Albergoni V, Irato P (2005). Efficacy of zinc supplementation in preventing acute hepatitis in Long-Evans Cinnamon rats; Liver International. Aug; 25(4):888-95.

[5] Marona Hérida R. N. and Lucchesi M. B. B. (2004). Protocol to refine intestinal motility test in mice Laboratory Animals Ltd. Laboratory Animals 38, 257-260.

[6] McKee K.K, Tan C.P, Palyha O.C, Liu J, Feighner S.D, Hreniuk D.L, Smith R.G, Howard A.D, Van der Ploeg L.H (1997). Cloning and characterization of two human G protein-coupled receptor genes (GPR38 and GPR39) related to the growth hormone secretagogue and neurotensin receptors. Genomics, 46:426-434.

[7] Moechars D, Depoortere I, Moreaux B, de Smet B, Goris I, Hoskens L, Daneels G, Kass S, Ver Donck L, Peeters T, Coulie $\mathrm{B}$ (2006). Altered gastrointestinal and metabolic function in the GPR39- obestatin receptor-knockout mouse. Gastroenterology, 131:1131-1141.

[8] Jackson VR, Nothacker HP, Civelli O (2006). GPR39 receptor expression in the mouse brain. Neuroreport, 17:813-816.

[9] Zhang J.V, Ren P.G, Avsian-Kretchmer O et al., (2005). "Medicine: obestatin, a peptide encoded by the ghrelin gene, opposes ghrelin's effects on food intake," Science, vol. 310, no. 5750, pp. 996-999.

[10] Holst B, Egerod K.L, Schild E, Vickers S.P, Cheetham S, Gerlach L.O, Storjohann L, Stidsen C.E, Jones R, Beck-Sickinger A.G, Schwartz T.W (2007). GPR39 signaling is stimulated by zinc ions but not by obestatin. Endocrinology, 148:13-20.

[11] Nogueiras R.P, Pfluger S. Tovar et al., (2007). "Effects of obestatin on energy balance and growth hormone secretion in rodents," Endocrinology, vol. 148, no. 1, pp. 21-26.

[12] Depoortere Inge (2012). GI functions of GPR39: novel biology. Current Opinion in Pharmacology 12:647-652.

[13] Mantzoros C.S, Prasad A.S, Beck F.W.J, Grabowski S, Kaplan J, Adair C and Brewer G.J (1998). Zinc May Regulate Serum Leptin Concentrations in Humans. Journal of the American College of Nutrition, Vol. 17, No. 3, 270-275.

[14] Casimiro-Lopes G, de Oliveira-Junior A.V, Portella E.S, Lisboa P.C, Donangelo C.M, de Moura E.G, Koury J.C (2009). Plasma Leptin, Plasma Zinc, and Plasma Copper Are Associated in Elite Female and Male Judo Athletes. Biological Trace Element Research 127:109-115.

[15] Grunfeld C, Zhao C and Fuller J et al., (1996). Endotoxin and cytokines induce expression of leptin, the ob gene product, in hamsters. Journal of Clinical Investigation 97:2152-2157.

[16] Chen MD, Lin PY (2000). Zinc-induced hyperleptinemia relates to the amelioration of sucrose-induced obesity with zinc repletion. Obesity Research; 8:525-9.

[17] Chen MD, Yang VC, Alexander PS, Lin PY, Song YM (2001). Effects of selected minerals on leptin secretion in streptozotocin-induced hyperglycemic mice. Experimental Biology and Medicine (Maywood); 226:836-40.

[18] Wynne K, Stanley S, McGowan B and Bloom S (2005). Appetite control. Journal of Endocrinology 184, 291-318.

[19] Grill H.J and Kaplan J.M (2002). The neuroanatomical axis for control of energy balance. Frontiers in Neuroendocrinology 23 $2-40$.

[20] Elmquist J.K, Ahima R.S, Maratos-Flier E, Flier J.S and Saper C.B (1997). Leptin activates neurons in ventrobasal hypothalamus and brainstem. Endocrinology 138 839-842.

[21] Hosoi T, Kawagishi T, Okuma Y, Tanaka J and Nomura Y (2002). Brainstem is a direct target for leptin's action in the central nervous system. Endocrinology 143 3498-3504.

[22] Robertson RP, Zhou H and Slucca M (2011). A role for zinc in pancreatic islet $\beta$-cell cross-talk with the $\alpha$-cell during hypoglycaemia. Diabetes Obesity and Metabolism; 13 Suppl 1:S106-11

[23] Jing M.Y, Sun J.Y and Wang J.F (2008). The effect of peripheral administration of zinc on food intake in rats fed $\mathrm{Zn}$-adequate or Zn-deficient diets. Biological and Trace Elements Research; 124:144-56.

[24] McKinley MJ, Denton DA, Oldfield BJ, et al (2006).Water intake and the neural correlates of the consciousness of thirst. Journal of Seminar in Nephrology. 26:249-257.

[25] Fregoneze JB, Souza C, Cunha M, Ferreira H, De-Oliveira I, Barros L, Malbouisson M \& De-Castro-e-Silva E (1994). Acute effects of intra-cerebroventricular administration of zinc on the drinking behavior of rats induced by dehydration or central cholinergic and angiotensinergic stimulation. Brazilian Journal of Medical and Biological Research, 27: 2623-2633.

[26] Fregoneze J.B, Luz C.P, Castro L, Oliveira P, Lima A.K.S, Souza F, Maldonado I, Macêdo D.F, Ferreira M.G, Bandeira I.P.V, Rocha Jr. M.A, Carvalho F.L.Q. and De-Castro-e-Silva E (1999). Zinc and Water Intake in Rats: Investigation of Adrenergic and Opiatergic Central Mechanisms. Brazilian Journal of Medical and Biological Research 32: 1217-1222. 
[27] Antunes-Rodrigues J, McCann S.M, Rogers L.C, and Samson W.K (1985). Atrial natriuretic factor inhibits dehydration- and angiotensin II-induced water intake in the conscious, unrestrained rat. Proceedings of National Academy of Science USA 82: 8720-8723.

[28] Burrell L.M, Lambert H.J and Bayliss P.H (1992). Atrial natriuretic peptide inhibits fluid intake in hyperosmolar subjects. Journal of Clinical Science (London) 83: 35-39.

[29] McKinley M.J and Johnson A.K (2004). The Physiological Regulation of Thirst and Fluid Intake. News in Physiological Sciences 19: 1-6.

[30] Turton M.D, O’Shea D, Gunn I, Beak S.A, Edwards C.M, Meeran K, Choi S.J, Taylor G.M, Heath M.M, Lambert P.D et al., (1996). A role for glucagon-like peptide-1 in the central regulation of feeding. Nature 379 69-72.

[31] DeCastro-e-Silva E, Marinho CA, Soares T, Castro L, Sarmento C, Cunha M, Gonzalez V, Oliveira P, Nascimento T, Luz CP, Santana Jr P, DeOliveira IR and Fregoneze JB (1996). Calcium channel blockers inhibit the antidipsogenic effect of central injections of zinc in rats. Brazilian Journal of Medical and Biological Research, 29: 1651-1655.

[32] Stengaard-Pedersen K (1982). Inhibition of enkephalin binding to opiate receptors by zinc ions: possible physiological importance in the brain. Acta Pharmacologica et Toxicologica, 50: 213-220.

[33] Johnson A.K and Thunhorst R.L (1997). The neuroendocrinology of thirst and salt appetite: Visceral sensory signals and mechanisms of central integration. Frontiers in Neuroendocrinology, 18: 292-353.

[34] Furness J.B and Costa M (1987). The Enteric Nervous System. Churchill Livingstone, Edingburgh.

[35] Olsson C and Holmgren S (2001). The control of gut motility. Journal of Comparative Biochemistry and Physiology. A Molecular and Integrative Physiology. 128: 481-503

[36] Hansen M.B (2003). Neurohumoral control of gastrointestinal motility. Physiological Research: 52, 1-30.

[37] Maqbool S, Parkman H.P and Friedenberg F.K (2009). Wireless capsule motility: comparison of the Smart Pill GI monitoring system with scintigraphy for measuring whole gut transit. Digestive Diseases and Sciences. 2009; 54:2167-2174.

[38] Elinder F. and Arhem P. (2003). Metal ion effects on ion channel gating. Quarterly Review of Biophysics. 36: 373-427.
[39] Norgaard-Nielsen, K. and Gether, U. (2006). $\mathrm{Zn}^{2+}$ modulation of neurotransmitter transporters. Handbook of Experimental Pharmacology: 1-22.

[40] Egerod K.L, Holst B, Petersen P.S, Hansen J.B, Mulder J, Hokfelt T, Schwartz T.W (2007). GPR39 splice variants versus antisense gene LYPD1: expression and regulation in gastrointestinal tract endocrine pancreas, liver, and white adipose tissue. Journal of Molecular Endocrinology 21:1685-1698.

[41] Lauwers E, Landuyt B, Arckens L, Schoofs L and Luyten W (2006). Obestatin does not activate orphan g protein-coupled receptor GPR39. Biochemical and Biophysical Research Communication, 351:21-25.

[42] Yasuda S, Miyazaki T, Munechika K, Yamashita M, Ikeda Y and Kamizono A (2007). Isolation of $\mathrm{Zn}^{2+}$ as an endogenous agonist of GPR39 from fetal bovine serum. Journal of Receptor Signal Transduction Research, 27:235-246.

[43] Storjohann L, Holst B and Schwartz TW (2008). Molecular mechanism of $\mathrm{Zn}^{2+}$ agonism in the extracellular domain of GPR39. Federation of European Biochemical Societies Letters, 582:2583-2588.

[44] Chan Lingtak-Neander (2008). Opioid Analgesics and the Gastrointestinal Tract. Practical Gastroenterology Nutrition Issues in Gastroenterology, Series \#65 Carol Rees Parrish, R.D., M.S., Series Editor: 37-50.

[45] DeSchepper H.U, Cremonini F, Park M-I, et al., (2004). Opioids and the gut: pharmacology and current clinical experience. Journal of Neurogastroenterology and Motility; $16: 383-394$

[46] De Luca A, Coupar I.M (1996). Insights into opioid action in the intestinal tract. Pharmacology and Therapeutics; 2:103-115.

[47] Schetz J.A. Chu A and Sibley D.R (1999). Zinc modulates antagonist interactions with $\mathrm{D}_{2}$-like dopamine receptors through distinct molecular mechanisms 4. Journal of. Pharmacology and Experimental Therapeutics. 289: 956-964.

[48] Fowler C.B, Pogozheva I.D, LeVine H and Mosberg H.I (2004). Refinement of a homology model of the $\mu$-opioid receptor using distance constraints from intrinsic and engineered zinc binding sites. Biochemistry 43: 8700-8710.

[49] Liu Y, Teeter M.M, DuRand C.J and Neve K.A (2006). Identification of a $\mathrm{Zn}^{2+}$-binding site on the dopamine $\mathrm{D}_{2}$ receptor. Biochemical and Biophysical Research Communication. 339, 873-879 